\title{
Determinants of Web-Based E-Training Model to Increase E-Training Effectiveness of Non-Formal Educators in Indonesia
}

\author{
Joko Sutarto, Sungkowo Edi Mulyono, Imam Shofwan, Yudi Siswanto \\ Department of Nonformal Education of Universitas Negeri Semarang \\ A Building of Sekaran Gunungpati College Semarang, 50229, Indonesia
}

\begin{abstract}
The industrial revolution 4.0 era creates changes in all fields, including education with internet technology usage and the implementation. Electronic training (e-training) as a training medium is one aspect to achieve effective and efficient training goals for educators. This study purpose was to examine the web-based e-training determinant model to increase the e-training effectiveness of professional non-formal educators. It uses quantitative method with survey approach to 120 non formal educators who follow competence improvement training. Data was analyzed by confirmatory factor analysis and Structural Equation Modelling (SEM) using AMOS software. These study findings revealed that e-training model is more effective than face-to-face training. It is probed by the improvement of nonformal educator increase the professional competence. The SEM usage confirms that etraining providers leadership, e-training work climate, e-training learning methods and e-training principles learning indirectly have positive and significant effect on e-training effectiveness mediated by e-training implementation.
\end{abstract}

Keywords: e-training model, e-training effectiveness, non-formal educator competence

DOI: $10.7176 / \mathrm{JEP} / 10-24-05$

Publication date: August 31st 2019

\section{INTRODUCTION}

The industrial revolution 4.0 era has created many changes in human life. Marked by digital technology in field of knowledge and technology today, it needs competent human resources. Avoiding development of digital technology will creates human resources that primitive and isolated (Caputo, Cillo, Candelo, \& Liu, 2019). The education change can be seen from face to face learning toward internet or online learning. The training by government institutions or private companies is done to improve the competence of educators, employees and companies in places where they work. Online training will make effective and efficient. In addition, it encourages educators to improve competence in accordance with development of knowledge and technology (Andayani, Prastiti, \& Larasati, 2014).

The history of online education was started in 1960 at University of Illinois, Chicago, USA. They conducted lectures with a connected computer terminal system where students can access lecture material, and listed the recorded lectures (Peterson's, 2019). Furthermore, online education was conducted in Indonesia in 1999 by University of Indonesia by organizing a historical education system known as the Student Centered e-Learning Environment, well known as SCELE (Agus Setiawan, 2017). Along with times, E-Learning process as transformation in digital learning or training becomes more complex.

E-training is defined as a long-distance training process using Internet or Intranet, providing the knowledge needed for selected subjects or expertise to increase scientific level or to achieve rehabilitation, using computers, sound, video, multimedia, e-book, email, chat and discussion groups (Naoual Ben Amara, 2016). E-training is similar with e-learning in many ways, mainly thing in delivery method and technology usage, but e-training has shorter learning times that specifically designed to achieve specific learning or expertise. Based on this understanding, it can be concluded that e-training is electronic media for education and training activities in order to improve the skills and performance of participants in education and training.

The prime performance of Non-formal Educators can develop the potential of educators and students optimally, consistent with success of non-formal education units to make large contribution to improve of knowledge, attitudes, and skills of students in future. Non-formal educators are the key holders of future development human resources. They must master: (a) science and technology in according to globalization and transformation demands; and (b) a mature, solid and independent personality to reflects the true identity of true educators who have high dedication in developing future thinkers, heirs and future developers, namely non-formal education students.

The fulfilment of human resources in digital era can only be done if a nation has a good attention to world of education. Human resources are very important aspect for survival and development of a country. Human resources can master useful technology to do high quality education to produce high quality products. The technology sophistication level from education actors to do their work is largely determined by quality of the human resources. Education businesses must be able to take advantage of potential of technological advances for learning and development (Hewett, Becker, \& Bish, 2019). 
Law No. 13 year 2003, article 1 paragraph 9 on employment and training explained the training as the whole activity to give, to obtain, to improve and to develop work competencies, productivity, discipline, attitudes and work ethic at a certain level of skill and expertise in accordance with the levels and qualifications of positions and jobs. The existence of professional and dignified non-formal educators is an absolute requirement to create high quality education. The efforts to encourage the existence of professional educators in according to main task are continuously be trained to improve their competence. The contribution of skilled professionals in educational practice must be addressed in professional roles and positions, and how responsibility and accountability must be illustrated with many technology integration into professional services (Fenwick \& Edwards, 2016).

Training can increases knowledge and skills and also develops talent. The analysis results found that training program correlated with higher professional competence (Amaluis, 2014). The center for development of early childhood education and people education in Central Java (PP-PAUD and Dikmas Central Java) are the Technical Implementation Unit of Ministry of Education and Culture with the task to implement the development of models and quality of education to increase the competence of non-formal educators. All components to achieve successful e-training with sustainable e-training have a significant positive effect. However, it does not rule out the possibility of ineffective and inefficient training. This is underlies the researchers to conduct research on Determinant of ETraining Model to increase the Competence of Non-formal Educators (PAUD-Dikmas) in Central Java, Indonesia.

\section{METHODS}

This study uses a quantitative approach with survey methods. The quantitative approach is carried out by obtaining empirical data to allows researchers to see general trends underlying a person's or group's behavior through numeric data analysis (Amaluis, 2014). Research with numbers or predicted is a quantitative approach (Sugiyono, 2013). There were 187 educators who participated in competency improvement e-training for non-formal educators (PAUD-Dikmas) in Central Java. The samples are determined by non-probability sampling with purposive sampling technique.

The sampling technique does not provide the same opportunity for each element or population to be chosen as a sample and to determine the sample with certain considerations (Creswell, 2014). The samples are determined by Isaac and Michel formula with a 5\% error rate for 120 respondents (Isaac, S., \& Michael, 1995). The estimation method of Maximum Likelihood (MC) requires a minimum sample of 100 and a maximum of 200 (Imam Ghozali, 2007). Data was obtained collected by questionnaires through Google Form. This study uses a five-point Likert scale instrument to measure attitudes, opinions and perceptions of a person or group of people about social phenomena (Johns, 2010).

This study has six variables, namely: exogenous variables, intervening variables and endogenous variables. There are four exogenous variables are e-training providers leadership, e-training work climate, e-training learning methods, and e-training learning principles. There are one intervening variables, namely the e-training model implementation and one endogenous variable, namely the e-training effectiveness.

The data analysis is analyzed by Structural Equation Modelling (SEM) using AMOS 24.0 statistical software. The first step to examine the measurement model and structural model on exogenous and endogenous variables uses confirmatory factor analysis (CFA). The indicators validity and reliability to measure of latent variables should have factor loading value $\geq 0.5$. The consistency of instrument measurement should have construct reliability $\geq 0.6$. SEM analysis is conducted by assessing the estimation of goodness of fit in research model and hypothesis (Ferdinand, 2002). 


\section{RESULTS AND DISCUSSION}

Validity and Reliability Test

The analysis results for the validity test are shown in table 1 .

Table 1. Validity and Reliability Test Result

\begin{tabular}{|c|c|c|c|c|c|c|}
\hline Variables & Indicators & $\begin{array}{l}\text { Standard } \\
\text { Loading }\end{array}$ & Description & $\begin{array}{l}\text { Construct } \\
\text { Reliability }\end{array}$ & $\begin{array}{c}\text { Variance } \\
\text { extract }\end{array}$ & Description \\
\hline \multirow{8}{*}{$\begin{array}{l}\text { E-training } \\
\text { providers } \\
\text { leadership }\end{array}$} & $\mathrm{kp} 8$ & 0.675 & Valid & 0.814727061 & 0.554618509 & Reliable \\
\hline & $\mathrm{kp} 7$ & 0.54 & Valid & & & \\
\hline & kp6 & 0.508 & Valid & & & \\
\hline & $\mathrm{kp} 5$ & 0.617 & Valid & & & \\
\hline & $\mathrm{kp} 4$ & 0.604 & Valid & & & \\
\hline & $\mathrm{kp} 3$ & 0.6 & Valid & & & \\
\hline & $\mathrm{kp} 2$ & 0.545 & Valid & & & \\
\hline & $\mathrm{kp} 1$ & 0.668 & Valid & & & \\
\hline \multirow{6}{*}{$\begin{array}{l}\text { E-training } \\
\text { Climate }\end{array}$} & rikp1 & 0.675 & Valid & 0.793590203 & 0.643046504 & Reliable \\
\hline & ikp2 & 0.562 & Valid & & & \\
\hline & ikp3 & 0.64 & Valid & & & \\
\hline & ikp4 & 0.655 & Valid & & & \\
\hline & ikp5 & 0.612 & Valid & & & \\
\hline & ikp6 & 0.603 & Valid & & & \\
\hline \multirow{6}{*}{$\begin{array}{l}\text { E-training } \\
\text { Education Method }\end{array}$} & mp1 & 0.626 & Valid & 0.770827861 & 0.565878056 & Reliable \\
\hline & $\mathrm{mp} 2$ & 0.692 & Valid & & & \\
\hline & mp3 & 0.518 & Valid & & & \\
\hline & $\mathrm{mp} 4$ & 0.626 & Valid & & & \\
\hline & mp5 & 0.54 & Valid & & & \\
\hline & mp6 & 0.588 & Valid & & & \\
\hline \multicolumn{2}{|c|}{ E-training Learningpb7 } & 0.655 & Valid & 0.797684335 & 0.571318675 & Reliable \\
\hline \multirow{6}{*}{ Principles } & pb6 & 0.525 & Valid & & & \\
\hline & pb5 & 0.667 & Valid & & & \\
\hline & $\mathrm{pb} 4$ & 0.505 & Valid & & & \\
\hline & pb3 & 0.519 & Valid & & & \\
\hline & $\mathrm{pb} 2$ & 0.663 & Valid & & & \\
\hline & $\mathrm{pb} 1$ & 0.657 & Valid & & & \\
\hline \multirow{7}{*}{$\begin{array}{l}\text { E-Training } \\
\text { Implementation } \\
\text { Model }\end{array}$} & ime7 & 0.769 & Valid & 0.815766184 & 0.642535474 & Reliable \\
\hline & ime6 & 0.522 & Valid & & & \\
\hline & ime5 & 0.525 & Valid & & & \\
\hline & ime4 & 0.625 & Valid & & & \\
\hline & ime 3 & 0.608 & Valid & & & \\
\hline & ime2 & 0.651 & Valid & & & \\
\hline & ime1 & 0.644 & Valid & & & \\
\hline \multirow{9}{*}{$\begin{array}{l}\text { E-training } \\
\text { Effectiveness }\end{array}$} & kme9 & 0.674 & Valid & 0.875637468 & 0.786955582 & Reliable \\
\hline & kme8 & 0.663 & Valid & & & \\
\hline & kme7 & 0.688 & Valid & & & \\
\hline & kme6 & 0.643 & Valid & & & \\
\hline & kme5 & 0.629 & Valid & & & \\
\hline & kme4 & 0.591 & Valid & & & \\
\hline & kme3 & 0.689 & Valid & & & \\
\hline & kme2 & 0.772 & Valid & & & \\
\hline & kmel & 0.606 & Valid & & & \\
\hline
\end{tabular}

Table 1 shows standardized loading factors to measure errors from each indicator has a value of $\geq 0.5$. It can be concluded that all variables can be explained from each indicator or valid.

Table 1 also explains that value of construct reliability is above $\geq 0.60$. It means that instrument is reliable. The value of variance extracted shows the construct fulfil the minimum cut-off value requirement of 0.50 . It means that indicators used as observed variables can explain the latent variables. Variance Extracted value $\geq 0.05$ indicates good convergence (Imam Ghozali, 2007).

Confirmatory Factors Analysis

The goodness of fit test results of confirmatory factor analysis for exogenous variables is shown in table 2 . 
Table 2. Feasibility Test Results for Exogenous Variable

\begin{tabular}{lccc}
\hline \multicolumn{1}{c}{ Goodness of Fit Index } & Cut-off Value & Results & Model Evaluation \\
\hline$X^{2}$ Chi- Square Statistik & df, $\alpha \leq 5 \%$ & 532,116 & Good \\
Probability & $\geq 0,05$ & 0,056 & Good \\
CMIN/DF & $\leq 2,00$ & 1,617 & Good \\
GFI & $\geq 0,90$ & 0,966 & Good \\
AGFI & $\geq 0,90$ & 0,922 & Good \\
TLI & $\geq 0,90$ & 0,970 & Good \\
CFI & $\geq 0,90$ & 0,910 & Good \\
RMSEA & $\leq 0,08$ & 0,079 & Good \\
\hline
\end{tabular}

Table 2 shows the construct of research model has met the established goodness of fit criteria. The probability value of goodness of fit shows a value of 0.056 . This value has met the feasibility testing and categorized as good even though there are some marginal testing values. Solimun (2002) stated that based on parsimony principle, the model has been declared fit if one or two fit criteria for model has been met. The endogenous variable test with confirmatory factor analysis test results for goodness of fit test is shown in table 3.

Table 3. Feasibility Test Results of Endogenous Variable

\begin{tabular}{lccc}
\hline \multicolumn{1}{c}{ Goodness of Fit Index } & Cut-off Value & Results & Model Evaluation \\
\hline$X^{2}$ Chi- Square Statistik & df. $\alpha \leq 5 \%$ & 195.766 & Good \\
Probability & $\geq 0.05$ & 0.052 & Good \\
CMIN/DF & $\leq 2.00$ & 1.900 & Good \\
GFI & $\geq 0.90$ & 0.930 & Good \\
AGFI & $\geq 0.90$ & 0.873 & Marginal \\
TLI & $\geq 0.90$ & 0.980 & Good \\
CFI & $\geq 0.90$ & 0.928 & Good \\
RMSEA & $\leq 0.08$ & 0.041 & Good \\
\hline
\end{tabular}

Table 3 shows that the construct used in confirmatory factor analysis has met the goodness of fit criteria. The probability table on goodness of fit shows a value of 0.052 . This value is categorized as marginal, so it can be concluded that model is acceptable and feasible to use.

The data assumptions in SEM modelling are normal multivariate, absence of multicollinearity or singularity and outliers. Imam Ghozali (2007) stated that Maximum Likelihood (ML) estimation technique is more efficient and unbiased if the assumption of multivariate normality is fulfilled, namely at Critical Ratio (CR) $>2.58$ ). The data with normal multivariate data must be normal the univariate. On contrary, if the entire data is normal univariate, it is not a guarantee that it will be normal multivariate which outside the range \pm 2.58 . The test results with a value of 1.724 indicate that research data used has met the normality of data. In other words, this data study has been distributed normally. In addition, covariance matrix determinant of sample value is 4.512 . This value is far from zero, it means there are no multicollinearity and singularity problems. It has no multivariate outliers in data.

Analysis of Structural Equation Modelling (SEM)

Structural Equation Modelling (SEM) with full model is done after conducting confirmatory factor analysis on exogenous and endogenous variables. Figure 1 shows results of SEM analysis. 


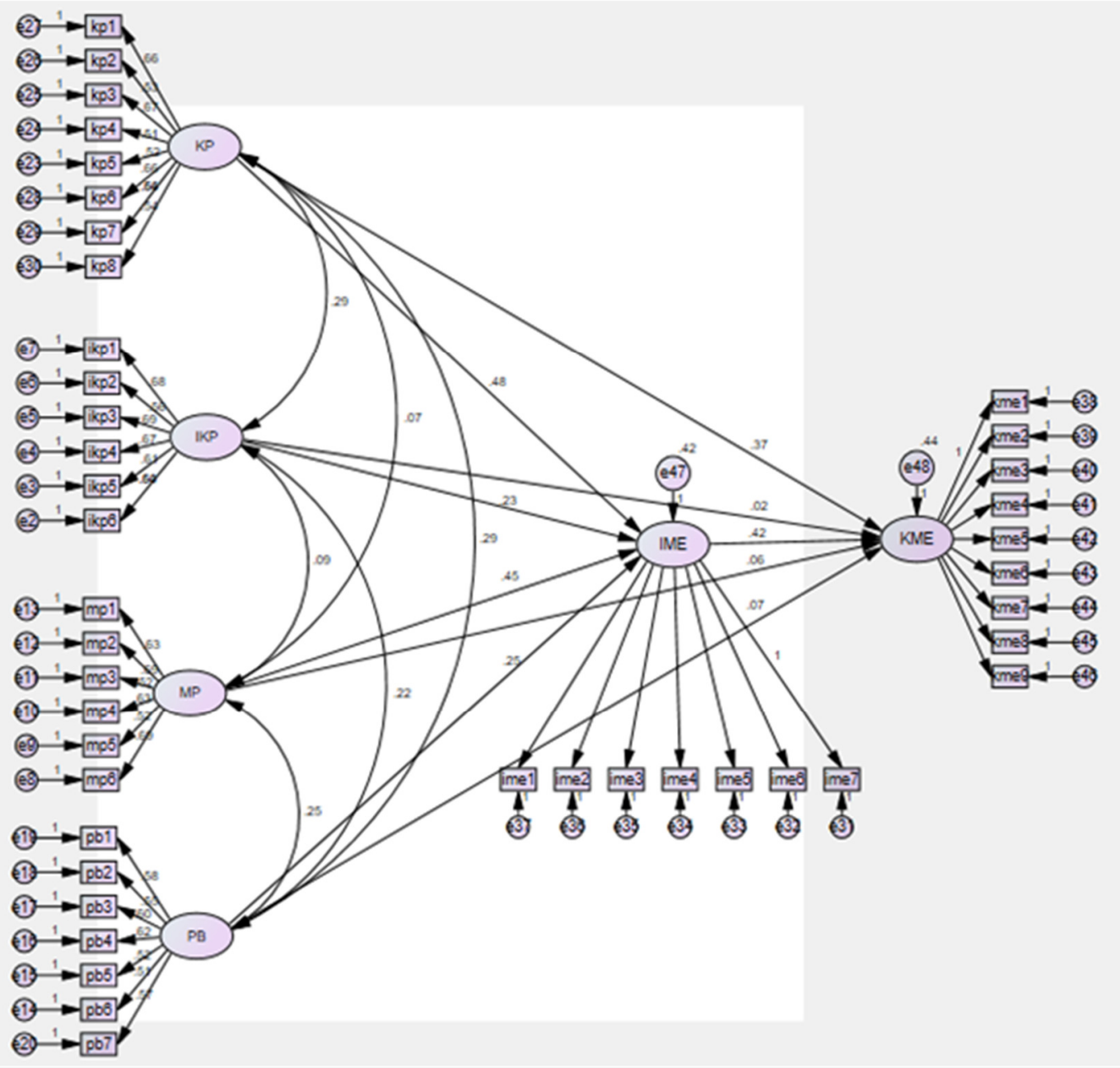

Description:

$\begin{array}{ll}\mathrm{KP} & =\text { e-training provider leadership } \\ \mathrm{IKP} & =\text { e-training work climate } \\ \mathrm{MP} & =\text { e-training method } \\ \mathrm{PB} & =\text { e-training principle } \\ \mathrm{IME} & =\text { e-training Implementation } \\ \mathrm{KME} & =\text { e-training Effectiveness }\end{array}$

Figure 1. Results of Structural Equation Modelling (SEM)

The results of feasibility model test or the goodness of fit is shown in table 4 .

Table 4. Goodness of Fit of the Model

\begin{tabular}{lccc}
\hline \multicolumn{1}{c}{ Goodness of Fit Index } & Cut-off Value & Results & Model Evaluation \\
\hline$X^{2}$ Chi- Square Statistik & df. $\alpha \leq 5 \%$ & 2094.356 & Good \\
Probability & $\geq 0.05$ & 0.093 & Good \\
CMIN/DF & $\leq 2.00$ & 1.843 & Good \\
GFI & $\geq 0.90$ & 0.982 & Good \\
AGFI & $\geq 0.90$ & 0.950 & Good \\
TLI & $\geq 0.90$ & 0.942 & Good \\
CFI & $\geq 0.90$ & 0.928 & Good \\
RMSEA & $\leq 0.08$ & 0.002 & Good \\
\hline
\end{tabular}

Table 4 shows that model used is acceptable at a significance level of 0.093 . It indicates the structural equation model in good category. It means the feasibility test of SEM model has met the requirements.

The next step is hypotheses testing. All hypotheses testing are done by looking at value of Critical Ratio (C.R) of the relationship from SEM analysis, as shown in table 5. 
Table 5. Hypotheses Testing of Each Variable

\begin{tabular}{lllllll}
\hline & \multicolumn{1}{c}{ Description } & $\begin{array}{c}\text { Std } \\
\text { Estimate }\end{array}$ & Estimate & S.E & C.R & P \\
\hline E_training_implementation & $\leftarrow$ E-training_providers_leadership & .482 & .588 & .232 & 2.534 & .011 \\
E_training_implementation & $\leftarrow$ E_training_work_climate & .232 & .759 & .650 & 2.168 & .043 \\
E_training_implementation & $\leftarrow$ E-training_method & .451 & 1.029 & .476 & 2.161 & .031 \\
E_training_implementation & $\leftarrow$ E_training_learning_principle & .251 & .122 & .558 & 2.219 & .027 \\
E-training_effectiveness & $\leftarrow$ E_Training_implementation & .417 & .227 & .085 & 2.664 & .008 \\
E-training_effectiveness & $\leftarrow$ E-training_providers_leadership & .371 & .246 & .124 & 2.987 & .047 \\
E-training_effectiveness & $\leftarrow$ E_training_work_Climate & .024 & .043 & .314 & 2.137 & .021 \\
E-training_effectiveness & $\leftarrow$ E-training_method & .058 & .072 & .197 & 2.368 & .013 \\
E-training_effectiveness & $\leftarrow$ E_training_learning_principle & .072 & .093 & .283 & 2.329 & .042 \\
\hline
\end{tabular}

\section{Model of Competency Enhancement of Early Childhood Education Educators in Central Java}

Estimation parameters to test the effect of organizer leadership on e-training effectiveness showed a C.R value of 2.987 with a probability of $<0.05$. It means the organizer leadership variable have a positive and significant effect on e-training effectiveness. Freifeld (2013) stated that leader role in training programs strengthen the participants' skills and knowledge, making participants more effective in strategy and execution.

Estimation parameters to test the effect of work climate in training on e-training effectiveness showed a C.R value of 2.137 with a probability of $<0.05$. It means the work climate variable has a positive and significant effect on e-training effectiveness. Neomi Kaplan-Mor, Chanan Glezer (2011) stated that ethical work climate is important because training that achieves excellence and high expectations through socially responsible behavior.

Estimation parameters to test the effect of e-training learning methods on e-training effectiveness showed a C.R value of 2.368 with probabilities $<0.05$. It means the e-training learning methods variable have a positive and significant effect on e-training effectiveness. Abdullah (2011) stated that the most important determinant in etraining method is to adjusts the situation and conditions of all e-training components to achieve effective results. The type of e-training method chosen also depends on the program objectives and expected learning outcomes.

Estimation parameters to test the effect of learning principle on e-training effectiveness shows the value of C.R of 2.329 with probabilities $<0.05$. it means the learning principle variable has a positive and significant effect on e-training effectiveness. Poon Teng Fatt (1993) said that no e-training program can ignore learning needs. Fulfilling the demands of 1990s need a personalized training to harmonize the learning environment with learning styles of students. Creating the best trainee is not an easy task. This is a continuing challenge for trainers to meet the higher demands in future. Therefore, it can be concluded that with e-training, principle of good learning will increase the e-training effectiveness.

\section{E-training model to increase the Competence of Non-formal Educators (PAUD-Dikmas) in Central Java} Estimation parameters to test effect of e-training providers leadership on e-training effectiveness through the etraining model implementations showed a C.R value of 2.534 with a probability value of $0.011<0.05$. So it can be concluded that e-training provider leadership indirectly has a positive and significant effect on e-training effectiveness mediated by e-training model implementation. Freifeld (2013) stated that leader's role in e-training programs to strengthen participants' skills and knowledge, makes participants more effective in strategy and execution. Therefore, it can be concluded that good e-training provider leadership in e-training will also increase the e-training effectiveness.

Estimation parameters to test the effect of work climate on e-training effectiveness through the e-training model implementations show a C.R value of 2.168 with a probability value of $0.043<0.05$. It means the work climate variable indirectly has a positive and significant effect on e-training effectiveness mediated by e-training model implementation. Anu Singh Lather (2009) stated that success of e-training program is determined from a work climate e-training perspective because it helps in achieving an effective e-training program. Therefore, it can be concluded that in e-training, good work climate e-training will also increase the e-training effectiveness.

Estimation parameters to test the effect of e-training learning methods on e-training effectiveness through the e-training model implementations show the value of C.R is 2.161 with a probability value of $0.031<0.05$. It means the variables e-training learning methods variable indirectly have a positive and significant effect on e-training effectiveness mediated by e-training model implementation. Neomi Kaplan-Mor, Chanan Glezer (2011) provided new insights on how an organization can utilize e-training methods effectively to achieve better operational excellence in training. Therefore, it can be concluded that with e-training, good e-training learning methods will increase the e-training effectiveness.

Estimation parameters to test the effect of learning principle on e-training effectiveness through the e-training model implementation show a C.R value of 2.219 with a probability value of $0.027<0.05$. It means the learning 
principle indirectly has a positive and significant effect on e-training effectiveness mediated by e-training model implementation. Poon Teng Fatt (1993) said that no e-training program can ignore learning needs. In fulfilling the 1990s demands, all we need is personalized training based on learning environment of trainee. Creating best trainee is not an easy task. This is a continuing challenge for trainers to meet the higher demands in future. Therefore, principle of good learning will increase the e-training effectiveness.

The estimation parameter to test effect of e-training model implementation on e-training effectiveness shows a C.R value of 2.664 with a probability $<0.05$. So it can be concluded that e-training model implementation has a positive and significant effect on e-training effectiveness. Ramayah, Ahmad, \& Hong (2012) states that e-training has an effect on cost effectiveness, flexibility, comfort, consistency of content throughout the organization. This study offers valuable insights for top management and IT managers related to factors affecting the effectiveness of e-training. Organizations can recognize the benefits brought by e-training, namely cost effectiveness, flexibility, convenience, consistency of content throughout the organization. Many do not recognize the critical factors that influence the success of e-training implementation.

\section{CONCLUSION}

This empirical study found that e-training model was more effective than face-to-face training based on an increase in professional competence of non-formal educators. The SEM procedures usage has confirmed that hypothetical model of leadership, e-training providers, work climate in e-training, e-training learning methods, e-training principles of e-training participants indirectly have a positive and significant effect on e-training effectiveness mediated by e-training implementation. The e-training model has the effect of attracting attention and giving rise to motivation of non-formal educators who take part in training to improve educator competence. This provides a strong justification that e-training model implementation variable not only stand as exogenous variables and as estimators of e-training effectiveness variables, but also as intervening variables to mediate the exogenous variables. This research should be replicated in other educational environments, as public and private formal education educators, so that e-training models can be developed to improve the professionalism of Indonesian educators to face competitive global word in future.

\section{REFERENCES}

Abdullah, H. (2011). Implementing Training in Manufacturing Firms: Training Methods, Venue and Provider. Retrieved from http://www.jgbm.org/page/7 Haslinda Abdullah.pdf

Agus Setiawan. (2017). Sejarah Singkat E-Learning dan E-Learning di Institusi Pendidikan di Indonesia. Retrieved from http://elearningbdlhksmd.blogspot.com/2017/01/sejarah-singkat-e-learning-dan-e.html

Amaluis, D. (2014). Analisis Efektifitas Program Pelatihan Diklat PIM III Terhadap Kompetensi Pejabat Eselon III di Pemerintah Kabupaten Agam. Journal of Economic and Economic Education, 3(1), 18-26.

Andayani, E. S., Prastiti, S. D., \& Larasati, I. P. (2014). E-Learning-Based Training Model for Accounting Teachers, 2, 194-200.

Anu Singh Lather, H. S. S. (2009). Role and Importance of Training Climate for Effective Training Programs. Enterprise Risk Management, 1(1), 72-82.

Caputo, F., Cillo, V., Candelo, E., \& Liu, Y. (2019). Innovating through digital revolution: The role of soft skills and Big Data in increasing firm performance. Management Decision. https://doi.org/10.1108/MD-07-20180833

Creswell, J. W. (2014). Research Design: Qualitative, Quantitative and Mixed Methods Approaches (4th ed.). Thousand Oaks: Sage.

Fenwick, T., \& Edwards, R. (2016). Exploring the impact of digital technologies on professional responsibilities and education. European Educational Research Journal, 15(1), 117-131. https://doi.org/10.1177/1474904115608387

Ferdinand. (2002). Metode Penelitian Manajemen : Pedoman penelitian untuk Skripsi, Tesis, dan Desertasi Ilmu Manajemen. Semarang: Badan Penerbit Universitas Diponegoro.

Freifeld, L. (2013). Emerging Training Leaders. Training, 50(3), 20-31.

Hewett, S., Becker, K., \& Bish, A. (2019). Blended workplace learning: the value of human interaction. Education and Training, 61(1), 2-16. https://doi.org/10.1108/ET-01-2017-0004

Imam Ghozali. (2007). Aplikasi Analisis Multivariate dengan Program SPSS). Semarang: Badan Penerbit Universitas Diponegoro.

Isaac, S., \& Michael, W. B. (1995). Handbook in research and evaluation: A collection of principles, methods, and strategies useful in the planning, design, and evaluation of studies in education and the behavioral sciences (3rd ed.). San Diego, CA, US: Edits publishers.

Johns, R. (2010). Survey question bank: Methods Fact Sheet 1, Likert items and scales. University of Strathclyde. Naoual Ben Amara, L. A. (2016). E-Training and Its Role in Human Resources Development. Global Journal of Human Resource Management, 4(1), 1-12. 
Neomi Kaplan-Mor, Chanan Glezer, M. Z. (2011). A comparative analysis of end-user training methods. Journal of Systems and Information Technology, 13(1), 25-42. https://doi.org/http://dx.doi.org/10.1108/MRR-092015-0216

Peterson's. (2019). The history of online education. Retrieved from https://www.petersons.com/blog/the-historyof-online-education/

Poon Teng Fatt, J. (1993). Learning styles in training: Teaching learners the way they learn. Industrial and Commercial Training, 25. https://doi.org/10.1108/EUM0000000001599

Ramayah, T., Ahmad, N. H., \& Hong, T. S. (2012). An assessment of e-training effectiveness in multinational companies in malaysia. Educational Technology and Society, 15(2), 125-137.

Solimun. (2002). Multivariate Analysis Structural Equation Modelling (SEM) Lisrel dan Amos. Malang: Fakultas MIPA, Universitas Brawijaya.

Sugiyono. (2013). Metode Penelitian Kuantitatif, Kualitatif dan R\&D. Bandung: Alfabeta. 